\title{
Economic Evaluation of Hydroponics and Other Treatment Options for Phosphorus Removal in Aquaculture Effluent
}

\author{
Paul R. Adler ${ }^{1}$ \\ U.S. Department of Agriculture-Agricultural Research Service, \\ 45 Wiltshire Road, Kearneysville, WV 25430-9802 \\ Jayson K. Harper \\ Department of Agricultural Economics and Rural Sociology, The Pennsylvania State University, \\ 214-A Armsby Building, University Park, PA 16802 \\ Fumiomi Takeda \\ U.S. Department of Agriculture-Agricultural Research Service, \\ 45 Wiltshire Road, Kearneysville, WV 25430-9802 \\ Edward M. Wade and Steven T. Summerfelt \\ The Conservation Fund's Freshwater Institute, P.O. Box 1889, Shepherdstown, WV 25443
}

\begin{abstract}
Consumer demand for fish has been increasing despite declining ocean fish catches. Aquaculture, the cultivation of freshwater and marine plants and animals, is one of the fastest growing segments of U.S. agriculture. In the period from 1987 to 1992 , sales of farm-raised trout increased by almost $20 \%$ to over $\$ 80$ million in the United States (Terlizzi et al., 1995). Other sectors of the industry are growing even faster, with an overall increase in sales of almost 52\% (to \$504 million) during this time period.
\end{abstract}

Three different methods have been used for aquacultural production: pond culture, flowthrough systems, and recirculating systems. Pond systems, the most widely practiced form of aquaculture in the United States, have been used for the production of catfish (Ictaluris sp.) and many other species. Flow-through systems involve the continual flow of water through a tank or raceway. Often, these systems have been used in conjunction with a high-yielding spring for trout (Oncorhynchus sp.) production. Recirculating systems are semi-closed systems, in which water flowing through a series of tanks or raceways is captured, treated, and reused. Recirculating systems use the least amount of water, which is an advantage in areas with either limited water resources or stringent discharge standards. A high degree of management expertise is needed to manage oxygen levels and water quality in these systems.

With the increase in production of fish also comes an increase in discharge of nutrient pollutants. Wastewater from aquaculture can pollute streams by adding excess nitrogen, phosphorus, and organic matter. Removal of

\footnotetext{
Received for publication 15 Mar. 1999. Accepted for publication 12 Sept. 1999. Use of trade names does not imply endorsement of the products named nor criticism of similar ones not named. The cost of publishing this paper was defrayed in part by the payment of page charges. Under postal regulations, this paper therefore must be hereby marked advertisement solely to indicate this fact.

${ }^{1}$ To whom reprint requests should be addressed.
} E-mail address: PAdler@afrs.ars.usda.gov these nutrients from wastewater is an important operation because these compounds play a critical role in eutrophication. Emphasis has been placed on phosphorus removal for two reasons: 1) phosphorus is often the most critical nutrient in eutrophication of freshwater; and 2) nitrogen removal processes are less efficient and more expensive (Ramalho, 1983). All states in the Northeastern United States have regulations regarding the discharge of aquacultural effluents (Ewart et al., 1995). Therefore, treatment of fishery effluents needs to be considered when planning aquacultural production systems. Aquacultural effluents are difficult to treat because they contain large volume flows carrying relatively dilute nutrients (e.g., $<1 \mathrm{mg} \cdot \mathrm{L}^{-1}$ of $\mathrm{P}$ ) (Heinen et al., 1996). However, treating the nutrients in aquacultural effluents may be important because, depending upon the receiving water, the total nutrient mass loading can contribute significantly to environmental degradation.

The Freshwater Institute maintains a highdensity recirculating system near Shepherdstown, W. Va., which has the capacity to produce $\approx 22.7 \mathrm{t}$ of rainbow trout (Oncorhynchus mykiss Walbaum) annually. Daily production of trout effluent is $\approx 109 \mathrm{~m}^{3}$. Adler et al. (1996a, 2000) have considered several nontraditional techniques for treatment of the effluent from this system, including hydroponic crop production in greenhouses. Hydroponic production of horticultural crops such as basil (Ocimum basilicum L.) and lettuce (Lactuca sativa L.) may be a way to treat the wastewater and also produce a profit for growers.

Predominant thinking regarding the use of food crops to clean aquaculture effluents has been that plants cannot remove nutrients in water to low levels without a reduction in productivity and quality. Because greenhouse space is expensive, maintaining maximum productivity is critical to sustaining a profitable operation.

Thin-film technology production system. Conventional hydroponic production of lettuce and basil using thin-film technology, also known as Nutrient Film Technique (NFT), was investigated as a method to remove $\mathrm{P}$ from an aquaculture effluent. Thin-film technology is a hydroponic crop production system in which plants grow in water that flows continuously as a thin-film over their roots. Water flow across the roots decreases the stagnant boundary layer surrounding each root, thus enhancing the mass transfer of nutrients to the root surface and permitting crops to maintain high productivity at steady-state $P$ levels above $0.3 \mathrm{mg} \cdot \mathrm{L}^{-1}$ (Chen et al., 1997).

In our initial study, lettuce plants were grown in long ( $21.9 \mathrm{~m}, 126$ plants) troughs on rainbow trout effluent flowing from one end of the trough to the other. This system removed $\mathrm{P}$ from an inlet concentration of $\approx 0.7 \mathrm{mg} \cdot \mathrm{L}^{-1}$ to an outlet concentration of a few $\mu \mathrm{g} \cdot \mathrm{L}^{-1}$. However, as solution $\mathrm{P}$ concentrations dropped below $\approx 0.3 \mathrm{mg} \cdot \mathrm{L}^{-1}$, tissue $\mathrm{P}$ concentrations decreased. Even so, growth was sustained until the $\mathrm{P}$ concentration within the plant dropped below the critical deficiency level $(0.35 \%$ to $0.4 \% \mathrm{P}$ on a dry weight basis for lettuce). At that point, $\mathrm{P}$ deficiency symptoms appeared, growth rate decreased, and the plants became unmarketable. Thus, conventional hydroponic technology (where all plants in the trough are the same age) could only remove $\approx 50 \%$ of the $\mathrm{P}$ while producing a marketable product. Although lettuce can remove $\mathrm{P}$ to $<0.3 \mathrm{mg} \cdot \mathrm{L}^{-1}$, a reduction in growth coincides with a further reduction in solution $P$ concentrations. As a result, the conveyor production strategy was developed to sustain plant productivity and health while removing dissolved $\mathrm{P}$ levels to $<0.01 \mathrm{mg} \cdot \mathrm{L}^{-1}$.

Conveyor production system. Fundamental concepts of plant nutrition were utilized to develop the conveyor production system, which produced healthy lettuce and basil without an apparent reduction in growth, while simultaneously removing $P$ to very low levels $\left(\mu \mathrm{g} \cdot \mathrm{L}^{-1}\right)$. [For a mechanistic understanding of plant nutrient uptake, see Adler et al. (1996d, 1996e)]. Plants have the capacity to absorb and store nutrients in excess of their immediate needs, a process called luxury consumption (Marschner, 1995). The conveyor crop production strategy enables plants to store $\mathrm{P}$ early in their growth cycle. This stored reser- 
voir of $\mathrm{P}$ can be remobilized to meet current plant needs and supplement the lower P influx rate, which occurs as $\mathrm{P}$ drops below $\approx 0.3$ $\mathrm{mg} \cdot \mathrm{L}^{-1}$ in the effluent. Phosphorus remobilization will maintain growth as long as the tissue $\mathrm{P}$ concentration remains above the critical deficiency level. At the front end of the thin-film troughs, where nutrient concentrations were highest, young plants absorbed and stored nutrients in excess of their immediate needs. Luxury consumption of nutrients during this early growth phase sustained the plants when they were moved towards the trough outlet, where nutrient concentrations in solution were too low for absorption kinetics to meet their growth needs. Cellular nutrient concentrations were sufficient to sustain growth even after the concentrations of nutrients in the water became limiting. This conveyor crop production scheme permitted the removal of $\mathrm{P}$ to very low levels $\left(\mu \mathrm{g} \cdot \mathrm{L}^{-1}\right)$ without an apparent reduction in plant productivity (Adler et al., 1996b). This contrasts with a conventional production scheme in which a gradient in growth and a reduction in plant quality would accompany the reduction in nutrient levels.

Standardwatertreatmentoptions. Removal of $\mathrm{P}$ from wastewater can be accomplished using chemical, physical, or biological methods. Chemical precipitation using either lime, alum, or ferric chloride is the method most commonly used by municipalities. Physical removal processes intercept $\mathrm{P}$ using pressuredriven membranes (ultrafiltration and reverse osmosis) and ion exchange (Water Pollution Control Federation, 1983).

Biological removal is based on the uptake of $\mathrm{P}$, beyond its normal microbial growth requirements, using activated sludge and anaerobic and aerobic processes. Examples of these types of systems are the anaerobic/ oxic (A/O) process, the Phostrip process, and the modified Bardenpho process (Droste, 1997). Although biological processes have certain advantages over the use of coagulant chemicals (for example, less sludge production and lower salinity effluent), removal of $\mathrm{P}$ is not one of them. Activated sludge processes result in the incorporation of $\approx 20 \%$ to $40 \%$ of the incoming $\mathrm{P}$ into the sludge (Ramalho, 1983). Phosphorus removal is also affected by temperature, aeration, and light. As a result, biological treatment alternatives are not considered as an option in this paper.

For the purposes of this study, seven treatment-based and one land-based effluent management options were evaluated and compared with the hydroponic resource recovery approach. Options were selected based on an expectation of at least $80 \%$ removal of $P$. The treatment-based options include various levels of technical sophistication and fixed and variable costs. The land-option would dispose of the effluent on various field crops through a sprinkler irrigation system.

The objective of our research program was to develop a production system that would allow plants to remove $>95 \%$ of the $\mathrm{P}$ in the rainbow trout effluent while producing a marketable product. The purpose of this study is to compare the cost of hydroponic production alternatives with those of traditional wastewater treatment options (chemical precipitation, physical removal, and land application).

\section{MATERIALS AND METHODS}

Rainbow trout effluent characteristics. The effluent was from the recirculating system for rainbow trout production at The Conservation Fund's Freshwater Institute, Shepherdstown, W. Va. The bulk effluent typically has a $\mathrm{pH}$ of 7.2 and contains about $6 \mathrm{mg} \cdot \mathrm{L}^{-1}$ total suspended solids and the following macronutrients $\left(\mathrm{mg} \cdot \mathrm{L}^{-1}\right)$ : $\mathrm{NO}_{3}-\mathrm{N}(25), \mathrm{P}(0.7), \mathrm{K}(5), \mathrm{Ca}$ (55), $\mathrm{Mg}$ (20), and S (9). In contrast, the spring water that supplied the fish culture system typically contained $\left(\mathrm{mg} \cdot \mathrm{L}^{-1}\right): \mathrm{NO}_{3}(3), \mathrm{P}$ $(<0.001)$, and $\mathrm{K}(3)$. In the effluent, nutrients most limiting to the plants were Fe, Mn, Mo, and $\mathrm{K}$, in decreasing order. A plant's productivity is determined by the nutrient present in lowest supply relative to its requirements. When other nutrients limit growth, $\mathrm{P}$ removal can be increased by adding those nutrients that are most limiting. To make $P$ the most limiting nutrient and thereby maximize $P$ removal, the following nutrients were added to the effluent: $0.1 \mathrm{mg} \cdot \mathrm{L}^{-1}$ Fe-EDDHA (LibFer SP, Allied Colloids, Suffolk, Va.), $0.1 \mathrm{mg} \cdot \mathrm{L}^{-1} \mathrm{Mn}$-EDTA (Librel Mn, Allied Colloids), $0.004 \mathrm{mg} \cdot \mathrm{L}^{-1}$ Mo [as $\left(\mathrm{NH}_{4}\right)_{6} \mathrm{Mo}_{7} \mathrm{O}_{24}$ ], and $15 \mathrm{mg} \cdot \mathrm{L}^{-1} \mathrm{~K}$ (as $\mathrm{K}_{2} \mathrm{SO}_{4}$ ).

Seedling growth conditions. 'Ostinata' lettuce (a butterhead type) and sweet basil were seeded into Oasis ${ }^{\circledR}$ cubes (LC-1 Horticubes, Smithers-Oasis, Kent, Ohio). The seedlings were placed into thin-film troughs and watered for the first $20 \mathrm{~d}$, with a recirculated complete nutrient solution (in mM): $3 \mathrm{Ca}\left(\mathrm{NO}_{3}\right)_{2}$, $4 \mathrm{KNO}_{3}, 1 \mathrm{KH}_{2} \mathrm{PO}_{4}$, and $2 \mathrm{MgSO}_{4}$. The solution also contained the following micronutrients $\left(\mathrm{mg} \cdot \mathrm{L}^{-1}\right)$ : $\mathrm{Fe}$ as $\mathrm{FeSO}_{4}(2.5)$ and DTPA (2.5), $\mathrm{B}$ as $\mathrm{H}_{3} \mathrm{BO}_{3}(0.5), \mathrm{Mn}$ as $\mathrm{MnSO}_{4}(1.0)$, $\mathrm{Zn}$ as $\mathrm{ZnSO}_{4}(0.05), \mathrm{Cu}$ as $\mathrm{CuSO}_{4}(0.02)$, and $\mathrm{Mo}$ as $\left(\mathrm{NH}_{4}\right)_{6} \mathrm{Mo}_{7} \mathrm{O}_{24}(0.01)$. The $\mathrm{pH}$ of the solution was adjusted to 6.0 with $\mathrm{KOH}$. A seedling could grow on effluent from the beginning if a hole in the Oasis ${ }^{\circledR}$ cube was extended down through the bottom to permit immediate entry of roots into effluent upon germination. Without the hole, plants became nutrient-starved because mass transfer of nutrients was poor when the roots were not directly in the solution. Because of relatively large diffusion distances, the only nutrients delivered to the roots before they emerged from the cube were by evapotranspiration or mass flow. At $20 \mathrm{~d}$, seedlings were moved to a nonrecirculating thin-film system configured with the conveyor production sequence. Seedlings introduced at regular time intervals near the inlet of a thin-film system were progressively moved in sequence as they matured toward the outlet where they were harvested (Fig. 1). Rainbow trout effluent was pumped with peristaltic pumps (model no. 7520-35; Cole Parmer Instrument Co., Chicago) at a constant flow rate of 250 and $300 \mathrm{~mL} \cdot \mathrm{min}^{-1}$ for basil and lettuce, respectively.
Six connected troughs, each $3.66 \mathrm{~m}$ long, formed the foundation for the conveyor production scheme. The troughs, roughly $10.2 \mathrm{~cm}$ $\times 3.66 \mathrm{~m}$ (Genova Products, Davison, Mich.), were covered with 1.6-mm PVC, having 3.18$\mathrm{cm}$ holes evenly spaced $17.5 \mathrm{~cm}$ apart, and planted with 21 seedlings. With this production strategy, the rate of biomass production per unit area, hydraulic loading rate, and effluent $\mathrm{P}$ concentrations were relatively constant. Each of the six sections represented $4 \mathrm{~d}$ in the system, so both lettuce and basil were in the system for $24 \mathrm{~d}$, for total production cycles of $44 \mathrm{~d}$. Every $4 \mathrm{~d}$, plants were harvested at the outlet end of the system, the plants in the remaining five sections were moved down one position and 20-d lettuce or basil seedlings were set into the system at the inlet end (Fig. 1). This cycle was repeated five times to move a given set of plants completely through the system to harvest. The number of sections can be greater or less than six. An increase in the number of sections will reduce the percentage of biomass removed with any one harvest and result in a more stable outlet concentration.

After steady-state planting and harvesting was achieved, the conveyor production system maintained plant productivity and health while removing $99 \%$ of the dissolved $\mathrm{P}$ and $60 \%$ of the nitrate from the flow (Adler et al., 1996b). Basil and lettuce removed $P$ to 0.003 $\mathrm{mg} \cdot \mathrm{L}^{-1}$ and $<0.001 \mathrm{mg} \cdot \mathrm{L}^{-1}$, respectively, from an influent concentration $>0.5 \mathrm{mg} \cdot \mathrm{L}^{-1}$. Rate of $\mathrm{P}$ removal was $>60 \mathrm{mg} \cdot \mathrm{m}^{-2} \cdot \mathrm{d}^{-1}$ and $\mathrm{N}$ removal was $980 \mathrm{mg} \cdot \mathrm{m}^{-2} \cdot \mathrm{d}^{-1}$. Plants absorb nutrients continuously; $\mathrm{N}$ absorption varies with the day/night cycle while absorption of $\mathrm{P}$ varies little (Adler et al., 1996a). Because plants remove nutrients continuously, storage facilities are not required to treat effluents.

\section{ECONOMIC EVALUATION}

\section{Hydroponic crop production as a treatment alternative}

Greenhouse cost. The cost of setting up a greenhouse would include the fixed costs of site preparation (crushed stone base and treated wooden baseboards), the structure (frames, sidewalls, gable ends, and the covering used), heating and ventilation (including a backup generator), and construction (Table 1). Because year-round production would be required, the costs of equipping the greenhouse for supplemental lighting, heating, and evaporative cooling are also included.

For developing cost estimates, a $9.14 \times$ 40.2-m arch-style greenhouse ( $1.83 \mathrm{~m}$ sidewall, $2.44 \mathrm{~m}$ to tie bars, and $4.57 \mathrm{~m}$ height to peak) was chosen because of its standard size and flexibility. Design parameters required spacing the arches on 1.83-m centers to handle a $110 \mathrm{~km} \cdot \mathrm{h}^{-1}$ wind load. A double polyethylene $(6 \mathrm{~mm})$ film would cover the greenhouse. Additional costs included the cost of supplemental lighting (22 fixtures with 24,000-h, $1000-\mathrm{W}$, high-pressure sodium lamps) and an evaporative cooler $\left(110 \mathrm{~m}^{3} \cdot \mathrm{min}^{-1}\right)$. A backup generator $(5 \mathrm{kw}$, liquified petroleum gas powered with auto transfer switch) was included in 


\section{Step 1 Harvest oldest section}

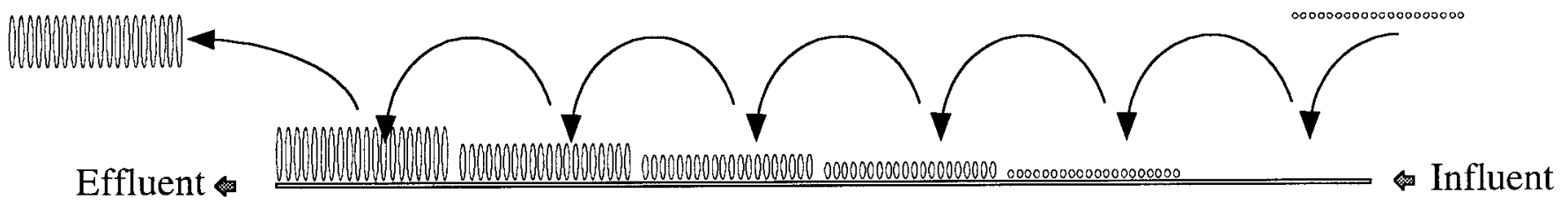

\section{Thin-film trough}

Fig. 1. Conveyor crop production schematic for hydroponic lettuce and basil.

fixed costs to prevent power disruptions.

Based on the water treatment capacity of lettuce and basil, three of these $9.14 \times 40.2-\mathrm{m}$ greenhouses would be required to treat $109 \mathrm{~m}^{3}$ of fishery effluent daily (effluent generated for a facility that produces $22.7 \mathrm{~m} \mathrm{t}$ of rainbow trout/year). For lettuce or basil production, this would represent an estimated total fixed cost of $\$ 82,970$ (Table 1). For conveyor production of lettuce or basil, $\approx 95 \%$ of the area of the greenhouses would be used and $5 \%$ would be used for starting plants.

Basil and lettuce hydroponics fixed costs. Basil and lettuce would be grown using NFT configured in the conveyor production system. Each crop would be grown in hydroponic trays (3.66-m troughs each containing 21 plants) supported by pipe benches. A total of 1332 trays of either lettuce or basil would be grown at one time. The setup cost for trays, tray supports, irrigation supply line, feeder tubes and fittings, injector pumps, solenoid valves, nutrient tanks, and submersible pumps for this system would be $\approx \$ 17,150$ (Table 1 ).

Basil and lettuce variable production costs. Each crop takes $\approx 44 \mathrm{~d}$ to produce, $24 \mathrm{~d}$ of which are spent in the greenhouse conveyor production system (Fig. 1, Table 2). The production schedule would call for starting 4662 plants in Oasis ${ }^{\circledR}$ cubes every $4 \mathrm{~d}$. During the first $12 \mathrm{~d}$ (days 1-12), the plants would be spaced $2.54 \times$ $2.54 \mathrm{~cm}$ and little management would be required other than fertilization and monitoring. From day 13 to 20 , the seedlings should be spaced $5.08 \times 5.08 \mathrm{~cm}$. On day 20 , the seedlings would be set in the hydroponic trays and moved into the greenhouse. Seedlings would be introduced at intervals near the inlet and progressively moved in sequence toward the outlet as they mature and are harvested (Fig. 1). For the next $24 \mathrm{~d}$ (days 21-44), the major management activities would be daily monitoring of irrigation system operation, general plant health, and pest populations. Application of an insecticidal soap may be necessary for control of white flies, thrips, and/or aphids. As harvesting occurs on every fourth day, the trays would be moved closer to the harvesting end of the greenhouse. On day 45, 4662 plants would be harvested, of which 95\% (4429) would be suitable for market. At the same time, a new group of seedlings would be brought into the greenhouse to continue the process.

Energy costs. Because hydroponic production will be required year-round to treat the fishery effluent, energy will be required for

Table 1. Fixed cost of three gutter-connected $9.14 \times 40.2-\mathrm{m}$ arch-style greenhouses with ventilation, lighting, heating, cooling, back-up generator, and hydroponic systems.

\begin{tabular}{lcc}
\hline \hline Components & Estimated fixed cost (\$ U.S.) & Projected life (years) \\
\hline Frames and sidewalls & Greenhouse & 20 \\
Gable ends & 13,430 & 20 \\
Wood baseboard & 2,400 & 10 \\
Double poly $(6 \mathrm{~mm})$ & 560 & 3 \\
Exhaust fans and vents & 2,350 & 10 \\
Heating system & 9,000 & 10 \\
Crushed stone base & 25,400 & 20 \\
Backup generator & 600 & 10 \\
Light fixtures & 4,200 & 10 \\
Electrical installation & 18,480 & 20 \\
Lamps & 2,970 & 8 \\
Evaporative cooler & 6,470 & 10 \\
Construction costs & 3,000 & 20 \\
Total greenhouse fixed cost & 14,110 & \\
& 82,970 & 20 \\
Tray supports & Hydroponic system & 10 \\
Hydroponic trays and covers & 3,780 & 5 \\
Supply line & 7,990 & 5 \\
Feeder tubes and fittings & 260 & 5 \\
Injector pumps & 1,410 & 5 \\
Solenoid valves & 1,650 & 5 \\
Nutrient tanks & 280 & $\underline{5}$ \\
Submersible pumps & 90 & \\
Total hydroponic system fixed cost & 1,690 &
\end{tabular}

operating greenhouse lighting, heating, and ventilation. Basil and lettuce will require supplemental lighting for $\approx 16 \mathrm{~h} \cdot \mathrm{d}^{-1}$ for 6 months. Electricity requirements for the greenhouse are dependent primarily on 22 high-pressure sodium lamps $(1000 \mathrm{~W})$ and two $1.5-\mathrm{kw}$ ventilation fans. Assuming a price of $\$ 0.06$ per $\mathrm{kw} \cdot \mathrm{h}^{-1}$, annual costs for electricity would average $\approx \$ 11,790$ (Table 2).

Heating of the greenhouse will be required from November through March in northeastern West Virginia. Based on standard heat loss estimates from the roof covering, walls and gable ends, total heat loss would be about equal to $1450 \mathrm{~mJ} \cdot \mathrm{h}^{-1}$ for three $9.14 \times 40.2-\mathrm{m}$ gutter-connected greenhouses (Harper et al., 1998). Based on construction and climatic factors and on an average desired temperature of $21.1^{\circ} \mathrm{C}$, total adjusted heat loss estimates indicate that $\approx 1.89$ million $\mathrm{mJ}$ of supplemental heat would be required (based on 1950-94 minimum temperatures at Kearneysville, W. Va.). Assuming that fuel oil heaters operate at around $80 \%$ efficiency and the supplemental lighting reduces heating costs by $25 \%$ (manufacturer estimate; General Electric Co., Fairfield, Conn.), then the annual variable cost for heating would average $\approx \$ 14,720$ (based on No. 2 fuel oil, which contains $\approx 27.0 \mathrm{~mJ} \cdot \mathrm{L}^{-1}$ and costs $\$ 0.22 / \mathrm{L}$ ).

Lettuce and basil profitability. Total annual variable costs (annual cash expenses) of growing lettuce or basil would be $\approx \$ 168,350$ for lettuce and $\$ 159,260$ for basil for the three gutter-connected greenhouses (Table 2). Total annual fixed costs (manager salary, depreciation, interest on investment, maintenance, insurance, taxes, and land) would be $\approx \$ 35,690$. To estimate potential profitability, the break-even price of the enterprise can be determined. This is the price needed to cover all the annual costs of production (variable cost of growing the crop and the fixed costs associated with the greenhouse and hydroponic investments) at a given yield. On an annual basis, the break-even price for basil is $\$ 0.53 /$ plant $\{[\$ 194,950$ (total cost $)+\$ 4500$ (transportation cost $)+\$ 9970$ (marketing commission)] divided by 398,600 plants $\}$. For lettuce, the break-even price is $\$ 13.18 /$ box $\{[\$ 204,040$ (total annual cost) + $\$ 4500$ (transportation cost) + \$10,430 (marketing commission)] divided by 16,608 boxes $\}$. Potential profitability is good for 
Table 2. Lettuce and basil production schedule and annual costs for three greenhouses.

\begin{tabular}{|c|c|}
\hline $\begin{array}{l}\begin{array}{l}\text { Growing costs } \\
\text { (per cohort) }\end{array} \\
\end{array}$ & $\begin{array}{c}\text { Estimated } \\
\text { cost (\$ U.S.) }\end{array}$ \\
\hline \multicolumn{2}{|c|}{ Day 1} \\
\hline \multicolumn{2}{|l|}{ Seed flats and cover (start } \\
\hline \multicolumn{2}{|l|}{4662 plants every 4 days) } \\
\hline Lettuce seed & 28 \\
\hline Basil seed & 22 \\
\hline Growing media & 96 \\
\hline Labor $(\$ 7 / \mathrm{h})$ & 52 \\
\hline \multicolumn{2}{|c|}{ Day $2-20$} \\
\hline Fertilizer & 2 \\
\hline Monitoring & 90 \\
\hline Spacing & 60 \\
\hline \multicolumn{2}{|c|}{ Day 20} \\
\hline Set in trays & 185 \\
\hline \multicolumn{2}{|c|}{ Day $21-44$} \\
\hline Monitoring & 120 \\
\hline Safer soap $(\times 1)$ & 4 \\
\hline Spraying & 15 \\
\hline Moving trays $(\times 6)$ & 180 \\
\hline \multicolumn{2}{|c|}{ Day 45} \\
\hline Harvest & 370 \\
\hline Boxes (lettuce) & 184 \\
\hline Bags (basil) & 89 \\
\hline Clean up & 185 \\
\hline Interest on operating capi & 5 \\
\hline \multicolumn{2}{|c|}{$\begin{array}{l}\text { Growing and packing costs } \\
\text { (for } 90 \text { harvests) }\end{array}$} \\
\hline Lettuce & 141,840 \\
\hline Basil & 132,750 \\
\hline \multicolumn{2}{|c|}{ Energy costs } \\
\hline Electricity $\left(\$ 0.06 \cdot \mathrm{kwh}^{-1}\right)$ & 11,790 \\
\hline Fuel Oil (\$0.22/L) & 14,720 \\
\hline \multicolumn{2}{|c|}{ Total annual variable costs } \\
\hline Lettuce & 168,350 \\
\hline Basil & 159,260 \\
\hline \multicolumn{2}{|c|}{ Annual fixed costs } \\
\hline Manager salary & 17,500 \\
\hline Depreciation & 9,540 \\
\hline Interest on investment & 4,010 \\
\hline $\begin{array}{l}\text { Maintenance, taxes, insur } \\
\text { and land }\end{array}$ & 4,640 \\
\hline Total annual fixed costs: & 35,690 \\
\hline
\end{tabular}

both crops, given that expected prices should exceed $\$ 0.60 /$ plant for basil and $\$ 14 /$ box for bibb lettuce (Table 3). Assuming these price levels, profits of $\$ 12,350$ for lettuce or $\$ 27,750$ for basil could be generated from the three $9.14 \times 40.2-\mathrm{m}$ gutter-connected greenhouses necessary to treat the $109 \mathrm{~m}^{3}$ of fishery effluent daily.

\section{Traditional water treatment options and cost estimates}

Cost estimates (Table 4) for each of these systems are based on the treatment of $109 \mathrm{~m}^{3}$ of effluent per day, were obtained from Gumerman et al. (1986), and were adjusted to 1995 dollars using engineering cost indexes [skilled labor and building cost indexes from Engineering News Record (1983, 1995)] and producer price indexes [general purpose machinery, concrete ingredients, steel mill products, miscellaneous general purpose machinery, and electrical machinery and equipment indexes from the U.S. Bureau of Labor Statistics (1982, 1983, 1995)].
Table 3. Lettuce and basil break-even prices for production from three greenhouses and profitability under different price assumptions.

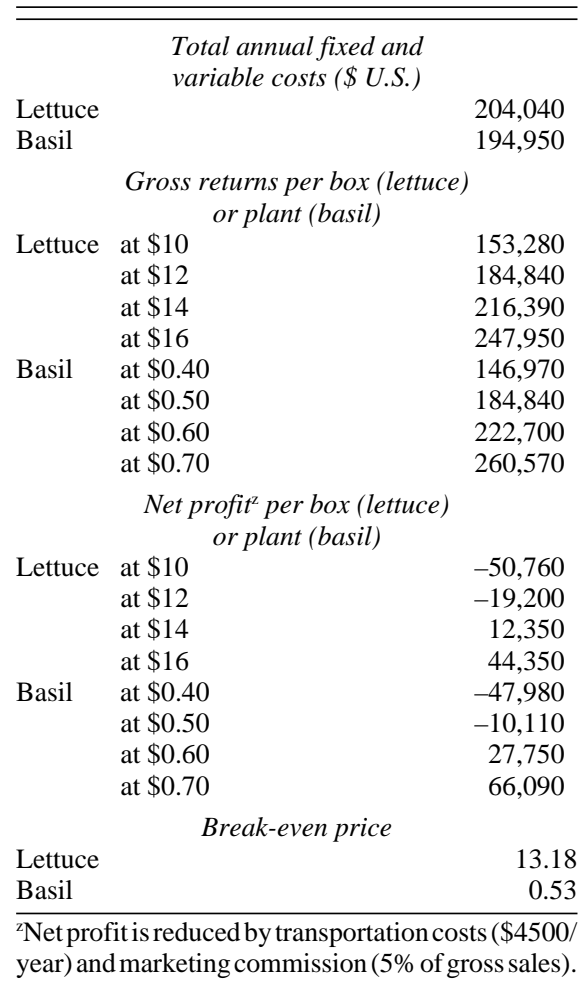

Chemical precipitation. Coagulants are chemicals used to remove turbidity and organic particulates, as well as inorganic particulates such as clay, silt, and mineral oxides, from raw water by precipitation (Montgomery, 1985). They overcome the charges of suspended particles, allowing larger particle groupings to form, and are added during the initial stage of water treatment through a mixing device that provides for rapid and thorough dispersion (Montgomery, 1985).

The most common rates of precipitants used for removal of $\mathrm{P}$ and their effectiveness are discussed by Ramalho (1983); this information is summarized as follows. 1) Ferric chloride at doses of $10 \mathrm{mg} \cdot \mathrm{L}^{-1}$ is the most commonly used precipitating agent. Phosphorus removal is $\approx 90 \%$. It is a cost-effective material, but very corrosive and requires special handling. 2) Lime at doses of 500-700 $\mathrm{mg} \cdot \mathrm{L}^{-1}$ is the most inexpensive precipitating agent. It removes, at most, $80 \%$ of the $\mathrm{P}$ and generates large volumes of sludge, which creates another disposal problem. 3) Alum used at doses of $200-250 \mathrm{mg} \cdot \mathrm{L}^{-1}$ provides the highest level of $\mathrm{P}$ removal at $\approx 95 \%$. Use of alum also removes $\approx 50 \%$ to $60 \%$ of organic materials (carbonaceous and nitrogenous), but is less often used because of its high relative cost. 4) Combinations of ferric chloride (at 2-5 $\mathrm{mg} \cdot \mathrm{L}^{-1}$ ) and lime (at $100-150$ $\mathrm{mg} \cdot \mathrm{L}^{-1}$ ) have also been used, resulting in $\approx 95 \%$ removal of $P$.

Precipitation involves the addition of the precipitant and the use of clarifiers. The fourth option, which uses a combination of ferric chloride and lime, is used for developing cost estimates. Lime requires a dry chemical feed system and ferric chloride requires a liquid chemical feed system capable of handling corrosive materials. Clarifiers allow for the sedimentation of contaminants from the wastewater by gravity. In a simple system, the precipitant would be added before passing the water through a single clarifer. In such a system, $70 \%$ to $90 \%$ removal of $P$ can be expected if good mixing is achieved (Bowker and Stensel, 1990). This system, in which the precipitation occurs in the primary clarifier, would represent an estimated total fixed cost of $\$ 110,800$. Annual fixed and variable costs would be $\approx \$ 15,300$ (system \#1, Table 5).

A system that allows for simultaneous precipitation would pass the wastewater through a primary clarifier before adding the precipitants. This is commonly done because it allows for flexibility in the application point. Removal of $80 \%$ to $95 \%$ of the $\mathrm{P}$ is possible (Bowker and Stensel, 1990). The wastewater is then sent through an aerator, which provides more thorough mixing, before the precipitants are removed in the secondary clarifier. This system has an estimated total fixed cost of $\$ 245,300$. Estimated annual fixed and variable cost would be $\$ 32,800$ (system \#2, Table 5).

The addition of a tertiary clarifier will further improve the removal of contaminants. In this system, the wastewater passes through a primary clarifier, aerator, and secondary clarifier before the precipitants are added. Precipitation occurs in the tertiary clarifier. The inclusion of an additional clarifier would raise the estimated total fixed cost of this system to $\$ 348,400$. Annual fixed and variable costs would be $\approx \$ 44,700$ (system \#3, Table 5).

Membrane treatment processes. Two membrane technologies that could be used for removing $\mathrm{P}$ are ultrafiltration and reverse osmosis. The process of making membranes from cellulose acetate for use in desalination was developed in the late 1950s and early 1960s. These technologies involve the application of pressure on the feedwater and a porous membrane. The feedwater flows across the membrane surface, preventing blockage. Depending on the porosity of the membrane, bacteria, viruses, toxic organic solutes, or dissolved salts can be excluded.

Ultrafiltration is an extremely compact system and does not require coagulation. It can remove suspended solids and particulates (including bacteria, colloids, and viruses), and pigments. Phosphorus, which occurs as discrete suspended or colloidal material, as well as microcolloids of calcium phosphate or iron and aluminum salts of phosphate, would be removed by ultrafiltration (Water Pollution Control Federation, 1983). Hollow fiber membranes are able to exclude particles down to $0.2 \mu \mathrm{m}$ from the water stream. Ultrafiltration is typically used for specialized applications requiring high purification and often serve as prefiltration for reverse osmosis and other treatment systems (Smith et al., 1991). An ultrafiltration system would initially cost $\approx \$ 93,000$ and its annual operating cost (fixed and variable) would be $\approx \$ 16,200$ (system \#4, Table 5). 
Table 4. Total fixed costs and annual variable operating costs (\$ US) ${ }^{\mathrm{z}}$ of chemical and physical methods for treatment of wastewater.

\begin{tabular}{|c|c|c|c|c|c|c|c|c|c|}
\hline & $\begin{array}{c}\text { Floculator/ } \\
\text { clarifier }\end{array}$ & $\begin{array}{c}\text { Ferric chloride } \\
\text { feed system }\end{array}$ & $\begin{array}{l}\text { Dry chemical } \\
\text { feed system }\end{array}$ & Aerator & $\begin{array}{c}\text { Contact } \\
\text { basin }\end{array}$ & $\begin{array}{c}\text { Ultra- } \\
\text { filtration }\end{array}$ & $\begin{array}{l}\text { Reverse } \\
\text { osmosis }\end{array}$ & $\begin{array}{c}\text { Ion } \\
\text { exchange }\end{array}$ & $\begin{array}{l}\text { Electro- } \\
\text { dialysis }\end{array}$ \\
\hline \multicolumn{10}{|c|}{ Fixed costs } \\
\hline Excavation and site work & 3,600 & 0 & 0 & 1,600 & 300 & 3,200 & 0 & 2,800 & 4,700 \\
\hline Manufactured equipment & 42,700 & 500 & 4,700 & 10,900 & 2,200 & 34,500 & 68,000 & 11,700 & 112,500 \\
\hline Concrete & 5,400 & 0 & 0 & 2,000 & 300 & 4,900 & 0 & 500 & 1,200 \\
\hline Steel & 0 & 0 & 0 & 5,700 & 0 & 0 & 0 & 0 & 0 \\
\hline Labor, installation & 8,800 & 200 & 300 & 3,600 & 800 & 7,000 & 1,800 & 1,500 & 2,300 \\
\hline Pipe and valves & 1,400 & 300 & 300 & 1,100 & 500 & 1,700 & 0 & 1,300 & 0 \\
\hline Electrical and instrumentation & 3,100 & 100 & 300 & 2,400 & 0 & 6,600 & 8,800 & 3,700 & 9,700 \\
\hline Housing & 24,600 & 0 & 0 & 0 & 0 & 18,900 & 19,700 & 12,500 & 23,400 \\
\hline Design contingencies $(+15 \%)$ & 13,500 & 200 & 800 & 4,100 & 600 & $\underline{11,500}$ & $\underline{14,700}$ & $\underline{5,100}$ & $\underline{23,100}$ \\
\hline Total fixed cost & 103,100 & 1,300 & 6,400 & 31,400 & 4,700 & 88,300 & 113,000 & 39,100 & 176,900 \\
\hline \multicolumn{10}{|c|}{ Variable costs } \\
\hline Labor & 1,300 & 1,500 & 500 & 1,800 & 100 & 3,700 & 4,200 & 2,400 & 5,100 \\
\hline Materials & 300 & 0 & 100 & 300 & 100 & 2,400 & 5,000 & 7,600 & 3,300 \\
\hline Electricity & 900 & 0 & 400 & 500 & 0 & 1,300 & 13,500 & 200 & 8,800 \\
\hline Interest on operating capital & 100 & 100 & 0 & 100 & 0 & 300 & 900 & 400 & 700 \\
\hline Depreciation (20 year life) & 5,200 & 100 & 300 & 1,600 & 200 & 4,400 & 5,700 & 2,000 & 8,800 \\
\hline Interest on investment & 4,100 & 100 & 300 & $\underline{1,300}$ & $\underline{200}$ & $\underline{3,500}$ & $\underline{4,500}$ & $\underline{1,600}$ & $\underline{7,100}$ \\
\hline Annual variable costs & 11,900 & 1,800 & 1,600 & 5,600 & 600 & 15,600 & 33,800 & 14,200 & 33,800 \\
\hline
\end{tabular}

${ }^{\mathrm{z}} \mathrm{All}$ costs rounded to the nearest $\$ 100$. All annual variable costs less than $\$ 50 /$ year are shown as zero.

Table 5. Total fixed and annual fixed and variable cost of wastewater treatment systems for phosphorus removal.

\begin{tabular}{|c|c|c|}
\hline System & $\begin{array}{l}\text { Total fixed } \\
\text { cost (\$ U.S.) }\end{array}$ & $\begin{array}{c}\text { Annual fixed and variable } \\
\text { cost (\$ U.S.) }\end{array}$ \\
\hline \multicolumn{3}{|l|}{ \# 1: Precipitation in primary clarifier } \\
\hline Ferric chloride feed system & 1,300 & 1,800 \\
\hline Dry chemical feed system & 6,400 & 1,600 \\
\hline Primary clarifier & 103,100 & 11,900 \\
\hline Total cost & 110,800 & 15,300 \\
\hline \multicolumn{3}{|l|}{ \# 2: Precipitation in secondary clarifier } \\
\hline Primary clarifier & 103,100 & 11,900 \\
\hline Ferric chloride feed system & 1,300 & 1,800 \\
\hline Dry chemical feed system & 6,400 & 1,600 \\
\hline Aerator & 31,400 & 5,600 \\
\hline Secondary clarifier & 103,100 & $\underline{11,900}$ \\
\hline Total cost & 245,300 & 32,800 \\
\hline \multicolumn{3}{|l|}{ \# 3: Precipitation in tertiary clarifier } \\
\hline Primary clarifier & 103,100 & 11,900 \\
\hline Aerator & 31,400 & 5,600 \\
\hline Secondary clarifier & 103,100 & 11,900 \\
\hline Ferric chloride feed system & 1,300 & 1,800 \\
\hline Dry chemical feed system & 6,400 & 1,600 \\
\hline Tertiary clarifier & 103,100 & $\underline{11,900}$ \\
\hline Total cost & 348,400 & 44,700 \\
\hline \multicolumn{3}{|l|}{ \# 4: Ultrafiltration } \\
\hline Contact basin & 4,700 & 600 \\
\hline Ultrafiltration system & 88,300 & 15,600 \\
\hline Total cost & $\overline{93,000}$ & $\overline{16,200}$ \\
\hline \multicolumn{3}{|l|}{ \# 5: Reverse osmosis } \\
\hline Contact basin & 4,700 & 600 \\
\hline Ultrafiltration system & 88,300 & 15,600 \\
\hline Reverse osmosis system & $\underline{113,000}$ & $\underline{33,800}$ \\
\hline Total cost & 206,000 & 50,000 \\
\hline \multicolumn{3}{|l|}{ \# 6: Ion exchange } \\
\hline Contact basin & 4,700 & 600 \\
\hline Ultrafiltration system & 88,300 & 15,600 \\
\hline Ion exchange system & 39,100 & 14,200 \\
\hline Total cost & 132,100 & 30,400 \\
\hline \multicolumn{3}{|l|}{ \# 7: Electrodialysis } \\
\hline Contact basin & 4,700 & 600 \\
\hline Ultrafiltration system & 88,300 & 15,600 \\
\hline Electrodialysis system & 176,900 & 33,800 \\
\hline Total cost & $\overline{269,900}$ & $\overline{50,000}$ \\
\hline \multicolumn{3}{|l|}{ \# 8: Hydroponic } \\
\hline Greenhouse and hydroponic system & $100,120^{z}$ & $-204,040^{y}$ \\
\hline Gross return & & $+216,390^{x}$ \\
\hline Net profit & & $+12,350$ \\
\hline
\end{tabular}

${ }^{2}$ Sum of total greenhouse and hydroponic system fixed costs (see Table 1).

${ }^{y}$ Sum of total annual fixed and variable costs for production of lettuce (see Table 2).

${ }^{\mathrm{x}}$ Gross returns for production of lettuce at $\$ 14 /$ box (see Table 3).
In reverse osmosis, only water molecules can pass through the membrane, so it is usually used only to produce purified water from saline or contaminated water supplies (Smith et al., 1991). Pretreatment of the feedwater is essential because performance is severely affected by contaminants, which form deposits on the membrane surface. Depending on pretreatment and the type of membrane used, reverse osmosis can remove $95 \%$ to $99 \%$ of the $\mathrm{P}$ in wastewater (Water Pollution Control Federation, 1991). Periodic backflushing and occasional chemical cleaning are necessary to maintain membrane filters. Typically, $90 \%$ of feed water is discharged as permeate (clean water) and $10 \%$ is discharged with the contaminants. This concentrated waste discharge requires careful disposal. Reverse osmosis is the most expensive option for removal of $\mathrm{P}$, with an estimated annual operating cost of $\$ 50,000$ (system \#5, Table 5). Its initial fixed cost would be $\approx \$ 206,000$.

Ion exchange. Ion exchange units are used to remove ionic substances from water. Typical units require prefiltration with a system like ultrafiltration. Contaminants are removed by absorption on an ion-exchange resin. In this process, one ion is exchanged for another on the charged surface of the resin, which is usually plastic. The resin chamber is saturated with the exchangeable ion before treatment. Ion exchangers typically use sodium chloride to saturate the exchange medium. Regeneration of the medium requires periodic recharging, causing downtime and producing a highly concentrated waste stream, which requires disposal.

A system using ion exchange would consist of a minimum of three processes. First, the water would be run into a contact basin to provide some initial settling. Then, the water would be passed through an ultrafiltration unit to remove particulates. Finally, the water would pass through the ion exchanger. Annual fixed and variable costs of ion exchange would be $\approx \$ 30,400$, of which $>\$ 6000$ would be for salt 
to regenerate the medium (system \#6, Table 5). Initial fixed costs would be $\approx \$ 132,100$.

Electrodialysis. Electrodialysis is a process that uses membranes and direct electrical current to attract ions to one side of the treatment chamber. The membranes allow the passage of either positively or negatively charged ions. Electrodialysis systems consist of three components: 1) a source of pressurized water; 2) a direct current power supply; and 3) a pair of selective membranes. Depending on the contaminants present, average ion removal varies from $25 \%$ to $60 \%$ per stage. As a result, multistage units are often used to increase the efficiency of removal. Pretreatment with a system like ultrafiltration is required to prevent fouling of the membranes. The annual fixed and variable costs of electrodialysis is quite high (only slightly less than for reverse osmosis) at $\$ 50,000$ per year (system \#7, Table 5). The initial fixed costs would be $\approx \$ 269,900$.

In all cases, the cost of removing $P$ from the fishery effluent using chemical or physical methods is quite high. The investment costs of such systems would be beyond the resources of most aquaculture production facilities. All these systems represent major fixed costs, additional management requirements, and in some cases, additional disposal problems. Treatment costs range from a low of $\$ 0.38 / \mathrm{m}^{3}$ for the primary clarifier to a high of $\$ 1.26 / \mathrm{m}^{3}$ for reverse osmosis and electrodialysis.

Land application. Land application of wastewater is another possible means of disposal. One advantage of such a system would be that the crop being irrigated with the nutrientcontaining effluent could then be sold to help offset the cost of management. Land application removes $\mathrm{P}$ through biological, chemical, and physical immobilization and plant uptake (Water Pollution Control Federation, 1983). The loading rate, and hence land area required, would depend on the crop grown and its ability to use the available $\mathrm{N}$ and $\mathrm{P}$. Land treatment can be characterized as slow rate, overland flow, or rapid infiltration. For this evaluation, slow rate was chosen because it has the widest range of acceptable soil types and permeabilities. Wastewater can be applied with sprinklers or by surface methods, with an annual loading rate of $0.5-6 \mathrm{~m}$ (Reed et al., 1995). For slow-rate systems, the concept of the limiting design factor is used to determine the minimum amount of land required. The critical design factor is the one that limits the loading rate (for example, $\mathrm{N}$ or $\mathrm{P}$ content, hydraulic capacity of the soil profile, etc.). Crop selection is very important with slow rate because it: 1) removes $\mathrm{N}$ and $\mathrm{P} ; 2$ ) increases water infiltration; and 3) produces revenue (Reed et al., 1995). Most slow-rate systems require some storage for periods when cold/wet conditions or crop planting/harvesting stops or slows wastewater applications (Reed et al., 1995). In slowrate systems, control of surface runoff is necessary; slopes of $2 \%$ to $6 \%$ are optimal (Reed et al., 1995).

Application of the wastewater would require a collection lagoon $\left(340 \mathrm{~m}^{3}\right.$ capacity; $>3 \mathrm{~d}$ flow), big-gun traveling sprinkler, deliv- ery pipe, pump, and power unit. Assuming an application rate of $1.9 \mathrm{~cm} \cdot \mathrm{d}^{-1}, \approx 4.05$ ha of cropland would be needed to dispose of the wastewater. Total fixed costs for the collection and distribution of the wastewater would be $\$ 56,800$, with an additional cost of $\$ 20,000$ for the land (4.05 ha at $\$ 4940 / \mathrm{ha})$. Annual operation costs (labor, fuel, maintenance, depreciation, and interest) would be $\approx \$ 11,360$ (Table 6). An appropriate crop would be one that provides both ground cover (to prevent erosion and runoff) and income potential. Alfalfa (Medicago sativa L.) or grass hay would be good choices, since both are perennial crops capable of making use of the $\mathrm{N}$ and $P$ in the effluent. Income potential based on the crop value, cost of production, and reduced fertilizer requirements would be $\approx \$ 3900$ for alfalfa and $\$ 2350$ for grass hay (Table 7). If alfalfa hay was the crop used, the net effect would be to reduce treatment costs to $\$ 7460$ per year or $\$ 0.18 / \mathrm{m}^{3}$. Compared with the chemical and physical treatment options, land application is considerably less expensive.

\section{CONCLUSIONS}

If all nutrients in the water being treated are equally limiting or balanced, nutrients can be removed to very low levels $\left(\mu \mathrm{g} \cdot \mathrm{L}^{-1}\right)$ by plants. Water with this same nutrient quality can be achieved only by the most advanced water treatment technology, such as ion ex- change, reverse osmosis, or electrodialysis. The most elaborate chemical removal systems are expensive and can only remove $\mathrm{P}$ to $\approx 0.1 \mathrm{mg} \cdot \mathrm{L}^{-1}$. In addition, chemical removal systems generate large amounts of sludge waste. Ion exchange generates a waste with regeneration of the resins, and reverse osmosis and electrodialysis clean a portion of the wastewater with membranes and concentrate ions removed into the waste stream. In contrast, the conveyor production system generates income while nutrients are removed to a very low level (Adler et al., 1996c, 1996f, 2000; Harper et al., 1998).

Conventional treatment alternatives for $\mathrm{P}$ in wastewater, whether they employ chemical precipitation, physical removal, or land application technologies, represent a significant additional cost to the owner of an aquaculture operation. Treatment costs vary from a low of $\$ 0.18 / \mathrm{m}^{3}$ for land application using alfalfa as the recipient crop to a high of $\$ 1.26 /$ $\mathrm{m}^{3}$ for reverse osmosis and electrodialysis. They also involve moderate to large investments in capital items that have few alternative uses.

Treatment of fishery effluent using hydroponic crop production represents a potentially profitable secondary enterprise for the aquaculture producer. Regardless of the crop chosen (lettuce or basil), expected crop prices appear to be more than sufficient to cover the costs of production at expected yields.

Table 6. Cost of irrigation system for land application of wastewater on agronomic crops ${ }^{2}$.

\begin{tabular}{lcc}
\hline Spray irrigation system & Cost $(\$$ U.S.) & Projected life (years) \\
\hline Collection lagoon $\left(340 \mathrm{~m}^{3}\right.$ capacity) & 21,800 & 20 \\
Big gun traveling sprinkler & 20,000 & 10 \\
Delivery pipe (used) & 3,000 & 10 \\
Pump and power unit & $\underline{12,000}$ & 12 \\
Total irrigation system cost & 56,800 & \\
Land cost $(4.05$ ha at $\$ 4940 /$ ha) & 20,000 & \\
Total fixed cost & 76,800 &
\end{tabular}

$\begin{array}{lc} & \text { Annual fixed and variable costs } \\ \text { Labor } & 1,220 \\ \text { Fuel } & 2,120 \\ \text { Oil } & 180 \\ \text { Repairs (power unit) } & 130 \\ \text { Repairs (irrigation unit) } & 100 \\ \text { Interest on operating capital } & 150 \\ \text { Depreciation } & 4,390 \\ \text { Interest on investment } & 3,070 \\ \text { Total annual fixed and variable costs } & 11,360\end{array}$

${ }^{2}$ Cost estimates are based on $2080 \mathrm{~L} \cdot \mathrm{min}^{-1}$ hose pull traveler, $75 \mathrm{kw}$ diesel w/centrifugal pump, and fuel consumption of $0.34 \mathrm{~L} \cdot \mathrm{kwh}^{-1}$.

Table 7. Annual production and cost of wastewater treatment using land application of aquacultural effluents on 4.05 ha of agronomic crops.

\begin{tabular}{|c|c|c|c|c|c|c|}
\hline Crop & $\begin{array}{l}\text { Irrigated } \\
\text { production } \\
\text { (t) }\end{array}$ & $\begin{array}{l}\text { Value of } \\
\text { production } \\
\text { (\$ U.S.) }\end{array}$ & $\begin{array}{l}\text { Cost of } \\
\text { production } \\
(\$ \text { U.S.) }\end{array}$ & $\begin{array}{c}\text { Value of fertilizer } \\
\text { removed by } \\
\text { crop }^{x} \\
\text { (\$ U.S.) }\end{array}$ & $\begin{array}{l}\text { Cost of } \\
\text { irrigation } \\
\text { system } \\
\text { (\$ U.S.) }\end{array}$ & $\begin{array}{c}\text { Cost of land } \\
\text { application of } \\
\text { wastewater } \\
\text { (\$ U.S.) }\end{array}$ \\
\hline Corn grain & 44.5 & 4640 & 2800 & 630 & 11,360 & 8890 \\
\hline Corn silage & 272.6 & 6910 & 3140 & 850 & 11,360 & 6750 \\
\hline Alfalfa hay & 63.6 & 7010 & 4280 & 1170 & 11,360 & 7460 \\
\hline Grass hay & 54.7 & 4800 & 3300 & 850 & 11,360 & 9010 \\
\hline Wheat grain & 24.7 & 3600 & 2000 & 580 & 11,360 & 9180 \\
\hline
\end{tabular}

${ }^{\mathrm{z}}$ Corn grain is valued at $\$ 104 / \mathrm{t}$, corn silage at $\$ 25 / \mathrm{t}$, alfalfa hay at $\$ 110 / \mathrm{t}$, grass hay at $\$ 88 / \mathrm{t}$, and wheat grain at $\$ 146 / t$.

${ }^{y}$ Cost of production figures are adapted from Harper (1998).

${ }^{x}$ Value of fertilizer is calculated based on standard crop removal rates and $\$ 0.57 / \mathrm{kg}$ for $\mathrm{N}$ and $\$ 0.55 / \mathrm{kg}$ for $\mathrm{P}$. 
The primary drawbacks of hydroponic production as a treatment alternative would be the added technical sophistication, labor, and marketing expertise required. Compared with conventional treatment alternatives that require relatively little additional management or labor, hydroponic production is much more risky. Development of a marketing plan is crucial. Sufficient attention must be paid to the day-to-day operation of the greenhouses and the servicing of markets for the produce or the better profitability of hydroponic production for the treatment of fishery effluent rapidly disappears.

\section{Literature Cited}

Adler, P.R. 1998. Phytoremediation of aquaculture effluents. Aquaponics J. 4:10-15.

Adler, P.R., J.K. Harper, E.M. Wade, F. Takeda, and S.T. Summerfelt. 2000. Economic analysis of an aquaponic system for the integrated production of rainbow trout and plants. Intl. J. Recirculating Aquaculture 1(1):15-34.

Adler, P.R., S.T. Summerfelt, D.M. Glenn, and F. Takeda. 1996a. Evaluation of a wetland system designed to meet stringent phosphorus discharge requirements. Water Environ. Res. 68:836-840.

Adler, P.R., S.T. Summerfelt, D.M. Glenn, and F. Takeda, 1996b. Evaluation of the effect of a conveyor production strategy on lettuce and basil productivity and phosphorus removal from aquaculture wastewater. In: J. Staudenmann, A. Schönborn, and C. Etnier (eds.). Recycling the resource: Ecological engineering for wastewater treatment. Environ. Res. Forum 5-6:131136.

Adler, P.R., F. Takeda, D.M. Glenn, and S.T. Summerfelt. 1996c. Enhancing aquaculture sustainability utilizing byproducts. World Aquaculture 27:24-26.

Adler, P.R., F. Takeda, D.M. Glenn, E.M. Wade, S.T. Summerfelt, and J.K. Harper. 1996d.
Phytoremediation of wastewater using lettuce and basil. Proc. Amer. Soc. for Plasticulture 26:253-258.

Adler, P.R., F. Takeda, D.M. Glenn, E.M. Wade, S.T. Summerfelt, and J.K. Harper. 1996e. Conveyor production strategy enhances nutrient byproduct recovery from aquaculture wastewater, p. 431-440. In: G.S. Libey and M.B. Timmons (eds.). Successes and failures in commercial recirculating aquaculture. NRAES-98. Northeast Reg. Agr. Eng. Serv., Ithaca, N.Y. July 1996.

Adler, P.R., F. Takeda, D.M. Glenn, E.M. Wade, S.T. Summerfelt, and J.K. Harper. 1996f. Nutrient removal: Ecological process sows a costsaving idea for enhancing water quality. Water Environ. and Technol. 8:23-24.

Bowker, R.P.G. and H.D. Stensel. 1990. Phosphorus removal from wastewater. Pollution Technol. Rev. 189. Noyes Data Corp., Park Ridge, N.J.

Chen, X.G., C. Gastaldi, M.Y. Siddiqi, and A.D.M. Glass. 1997. Growth of a lettuce crop at low ambient nutrition concentrations: A strategy designed to limit the potential for eutrophication. J. Plant Nutr. 20:1403-1417.

Droste, R.L. 1997. Theory and practice of water and wastewater treatment. Wiley, New York.

Engineering News-Record. 1983. Market trends, cost indexes. Engineering News-Record, 8 Dec. 1983, p. 63.

Engineering News-Record. 1995. Market trends, cost indexes. Engineering News-Record, $28 \mathrm{Aug}$. 1995, p. 110.

Ewart, J.W., J. Hankins, and D. Bullock. 1995. State policies for aquaculture effluents and solid wastes in the Northeast region. NRAC Bul. No. 300. Northeastern Reg. Aquaculture Ctr., Univ. Massachusetts-Dartmouth.

Gumerman, R.C., B.E. Burris, and S.P. Hansen. 1986. Small water system treatment costs. Pollution Technol. Rev. No. 136. Noyes Data Corp. Park Ridge, N.J.

Harper, J.K. 1998. Farm management: Enterprise budgets. In: The agronomy guide, 1999-2000. College of Agr. Sci., Coop. Ext., The Pennsyl- vania State Univ., University Park.

Harper, J.K., P.R. Adler, F. Takeda, E.M. Wade, and S.T. Summerfelt. 1998. Economic evaluation of treatment options for phosphorus in fishery effluent. Staff paper \#318. May 1998. Dept. of Agr. Econ. and Rural Soc., The Pennsylvania State Univ., University Park.

Heinen, J.M., J.A. Hankins, and P.R. Adler. 1996. Water quality and waste production in a recirculating trout-culture system with feeding of a higher-energy or a lower-energy diet. Aquaculture Res. 27:699-710.

Marschner, H. 1995. Mineral nutrition of higher plants. $2^{\text {nd }}$ ed., Academic, Harcourt Brace, London.

Montgomery, J.M. 1985. Water treatment principles and design. Wiley, New York.

Ramalho, R.S. 1983. Introduction to wastewater treatment processes. $2^{\text {nd }}$ ed., Academic, New York.

Reed, S.C., R.W. Crites, and E.J. Middlebrooks. 1995. Natural systems for waste management and treatment. $2^{\text {nd }}$ ed. McGraw-Hill, New York.

Smith, J.E. Jr., R.C. Renner, B.A. Hegg, and J.H. Bender. 1991. Upgrading existing or designing new drinking water treatment facilities. Pollution Tech. Rev. 198. Noyes Data Corp., Park Ridge, N.J.

Terlizzi, D.E., T. Ford, G.L. Greaser, and J.K. Harper. 1995. Introduction to aquaculture. Agr. Alternatives the Series, Dec. 1995. Coop. Ext. Serv., The Pennsylvania State Univ., University Park.

U.S. Dept. of Labor. Bureau of Labor Statistics. 1982. Producer prices and price indexes for June 1982. Govt. Printing Office, Washington, D.C.

U.S. Dept. of Labor. Bureau of Labor Statistics. 1983. Producer prices and price indexes for December 1983. Govt. Printing Office, Washington, D.C.

U.S. Dept. of Labor. Bureau of Labor Statistics. 1995. Producer Prices and Price Indexes for July 1995. Govt. Printing Office, Washington, D.C.

Water Pollution Control Federation. 1983. Nutrient control. Manual of practice FD-7. Water Pollution Control Fed., Alexandria, Va. 